\title{
Tobacco Habits among the 8 to 15 Years School Children of Rural Haryana
}

\author{
${ }^{1}$ Vidya Rattan, ${ }^{2}$ Utkal Mohanty, ${ }^{3}$ Ashima Goyal
}

\section{ABSTRACT}

Aim: The present cross-sectional study was undertaken to determine the prevalence and age at initiation of tobacco use among school children in rural areas of Haryana.

Materials and methods: A cluster sample design was used to produce a representative sample of schools from Panchkula and Ambala district. All students were included from the selected schools and information regarding tobacco use was collected from students of class 3 to 10 (8-15 years) through a self-administered questionnaire.

Results: A total of 3526 students with average age of $12.2 \pm$ 2.3 years were screened for tobacco use. About $182(5.1 \%)$ school children were found to be ever users of tobacco and 79 $(2.2 \%)$ were current tobacco users in any form. Peer pressure was found to be the most common cause of initiating tobacco use by the students.

Conclusion: Prevalence of tobacco use among the school children of rural Haryana is lower than that reported in urban areas by Global Youth Tobacco Survey (GYTS). However, the downward shift of the age at initiation ( $<10$ years) is a matter of grave concern, which needs to be tackled by creating suitable school environment through health promotion and strengthening anti tobacco laws.

Keywords: Tobacco, Smoking, Gutka chewing.

How to cite this article: Rattan $\mathrm{V}$, Mohanty $U$, Goyal A. Tobacco Habits among the 8 to 15 Years School Children of Rural Haryana. J Postgrad Med Edu Res 2014;48(4):183-185.

Source of support: Nil

Conflict of interest: None

\section{INTRODUCTION}

Tobacco use is one of the major causes of preventable deaths across the globe, and specifically in developing nations like India, it has become a dreadful killer. ${ }^{1}$ Nearly six million people die due to tobacco use every year and this figure will increase to eight million tobacco attributable deaths per year by 2030, of which, majority deaths will occur in the developing countries. ${ }^{2}$ In India, nearly one in ten adolescents in the age group 13 to 15 years have

${ }^{1}$ Additional Professor, ${ }^{2}$ Former Senior Resident, ${ }^{3}$ Professor

${ }^{1-3}$ Department of Oral Health Sciences Center, Postgraduate Institute of Medical Education and Research, Chandigarh, India

Corresponding Author: Vidya Rattan, Additional Professor Department of Oral Health Sciences Center, Postgraduate Institute of Medical Education and Research, Chandigarh, India Phone: 9914208718, e-mail: drvidyarattan@gmail.com ever smoked cigarettes and almost half of these, initiate tobacco use before 10 years of age. ${ }^{1}$ Since, most of the young people in developing countries are currently nontobacco users, they become special target groups for the tobacco industry. Everyday about 80,000 to 100,000 young people initiate smoking, most of them in the developing countries. ${ }^{3}$ Tobacco use, through both smoking and nonsmoking form plays a pivotal role in development and progression of cancer. It is also a significant risk factor in the development of a wide spectrum of oral diseases and conditions, ${ }^{4-6}$ e.g. smoker's melanosis, keratotic patches, nicotinic stomatitis, leukoplakia, palatal erosions, black hairy tongue, tooth staining, abrasions, periodontitis, gingivitis and weakened defence and repair ability of the gingival tissue. ${ }^{6,7}$ The Global Youth Tobacco Survey (GYTS) India report suggests that $14.1 \%$ of school children aged 13 to 15 years, currently use any of the available tobacco products. ${ }^{8}$ During oral health education programs in schools of rural Haryana, it was found that children of very tender age group consume tobacco products in all forms. Till date no Indian study is available depicting tobacco habits in children below 10 years. Therefore, present cross-sectional study was undertaken to determine the prevalence and age at initiation of tobacco use among school children of 8 to 15 years age group in rural areas of Haryana.

\section{OBJECTIVES}

1. To assess the prevalence of tobacco habits among school children.

2. To determine the age of initiation of these habits.

\section{MATERIALS AND METHODS}

A cluster sample design was used to produce a representative sample of schools from Panchkula and Ambala district. These districts were chosen because of the close vicinity to Chandigarh. At the first stage, a list of all rural government schools having grades 3 to 10 was prepared. At the second stage, the schools were selected randomly from each area. Written permission was obtained from the principals of the schools to conduct the study. All students were included from the selected schools for the study. Information was collected from students of class 3 to 10 (age: 8-15 years) through a structured questionnaire. Students of 8 to 12 years of age were assisted to fill the 
questionnaire. Complete anonymity (name of student, class or school) was maintained in the questionnaire and during screening.

\section{RESULTS}

A total of 3526 students were screened out of which 2310 (65.6\%) were boys and 1216 (34.4\%) were girls. Average age of the students was $12.2 \pm 2.3$ years. The predominant occupation of the fathers was agriculture and most of the mothers were housewives.

\section{Prevalence of Risk Behavior}

About 182 (5.1\%) school children were found to be ever users of tobacco in any form of which 57 (1.6\%) used in smoking form, 87 (2.4\%) used in chewable form and 38 $(1.0 \%)$ used a combination of both forms (Table 1). About $113(4.8 \%)$ were current tobacco users of which $18(0.7 \%)$ were smokers, 77 (3.3\%) were chewers and $18(0.7 \%)$ were users of both forms (Tables 2 and 3). Thirty-four (0.9\%) of the ever tobacco users initiated tobacco use below 10 years of age and the rest started after 10 years (Table 4 ). Gutka users consume on an average two-three sachets per day, bidi users consume one-two per day. Peer pressure was found to be the most common cause of initiating tobacco use by the students 165 (91\%), followed by 12 (7\%) watching elders in the family and $5(2 \%)$ used out of curiosity. Shops were the most common place to obtain

Table 1: Distribution of ever tobacco users

\begin{tabular}{llll}
\hline Habits & \multicolumn{2}{c}{ Gender } & \multirow{2}{*}{$\begin{array}{l}\text { Total } \\
\text { (3526) }\end{array}$} \\
\cline { 2 - 3 } & Boys & Girls & \\
& $N=2310$ & $N=1216$ & \\
\hline Ever tobacco users & $179(7.7 \%)$ & $3(0.2 \%)$ & $182(5.1 \%)$ \\
Ever tobacco chewers & $84(3.6 \%)$ & $3(0.2 \%)$ & $87(2.4 \%)$ \\
Ever tobacco smokers & $57(2.4 \%)$ & $0(0.0 \%)$ & $57(1.6 \%)$ \\
Ever users of both & $38(1.64 \%)$ & $0(0.0 \%)$ & $38(1.0 \%)$ \\
\hline
\end{tabular}

Table 2: Distribution according to current tobacco use habits

\begin{tabular}{llll}
\hline Habits & \multicolumn{2}{c}{ Gender } & \multirow{2}{*}{$\begin{array}{l}\text { Total } \\
\text { (3526) }\end{array}$} \\
\cline { 2 - 3 } & $\begin{array}{l}\text { Boys } \\
N=2310\end{array}$ & $\begin{array}{l}\text { Girls } \\
N=1216\end{array}$ & \\
\hline $\begin{array}{l}\text { Current tobacco users } \\
\begin{array}{l}\text { Current tobacco } \\
\text { chewers }\end{array}\end{array}$ & $113(4.8 \%)$ & $0(0 \%)$ & $113(3.2 \%)$ \\
$\begin{array}{l}\text { Current tobacco } \\
\text { smokers }\end{array}$ & $18(0.7 \%)$ & $0(0 \%)$ & $77(2.1 \%)$ \\
$\begin{array}{l}\text { Current users of both } \\
\text { Nmon }\end{array}$ & $18(0.7 \%)$ & $0(0 \%)$ & $18(0.5 \%)$ \\
\hline
\end{tabular}

Table 3: Distribution according to type of tobacco habits

\begin{tabular}{llll}
\hline Type of habits & \multicolumn{2}{c}{ Gender } & \multirow{2}{*}{$\begin{array}{l}\text { Total } \\
\text { (3526) }\end{array}$} \\
\cline { 2 - 3 } & Boys & Girls & \\
& $N=2310$ & $N=1216$ & \\
\hline Bidi & $35(1.5 \%)$ & $1(0.0 \%)$ & $36(1.0 \%)$ \\
Cigarette & $10(0.4 \%)$ & $0(0.0 \%)$ & $10(0.2 \%)$ \\
Gutka & $115(4.9 \%)$ & $2(0.1 \%)$ & $117(3.3 \%)$ \\
Khaini & $19(0.8 \%)$ & $0(0.0 \%)$ & $19(0.5 \%)$ \\
\hline
\end{tabular}

tobacco products for all age groups 115 (63\%), followed by obtaining from the friends 53 (29\%), whereas $14(8 \%)$ obtained it from home by stealing from elders. Among the current tobacco users, $73 \%$ tried to quit the habit compared to $27 \%$ who did not consider about quitting.

\section{DISCUSSION}

The prevalence of tobacco use among school children in different states of India has been reported to vary from 1.9 to $75.3 \% .^{9-12}$ The prevalence of ever tobacco users is $5.2 \%$ in the present study, which is lower than that reported by GYTS Haryana, i.e. 7.1\% and Chandigarh $9.2 \% .{ }^{13,14}$ Tobacco use was found mostly in boys and negligible among the girls in the present study as compared to GYTS Chandigarh, Haryana which reports $9.2 \%$ boys and $3.8 \%$ girls use tobacco in smoking form. This reflects the effect of rural and urban environment on the tobacco behavior among girls. To a certain extent it may be ascribed to conservative nature of the girls in the rural community unlike of urban areas where girls enjoy more freedom. Use of smokeless tobacco was more prevalent among the tobacco users as compared to smoking form and bidi was the smoking form used by majority of the smokers. This can be attributed to low or middle socioeconomic status (SES) of the government school children of rural areas, and majority of the elderly persons use bidi, hukka (smoking form) in these areas. Major environmental factors influencing tobacco behavior in these schools are easy accessibility and relatively inexpensive nature of chewable tobacco form. Tobacco products are available in close proximity to school campus and children below 18 years are not denied to purchase these in most of the areas. Elders in rural areas are also in a habit of asking the children to bring bidi, gutka, etc. from the shops, which make them more vulnerable to tobacco use. Majority of tobacco users responded influence of peer pressure as the major factor to initiate tobacco use, followed by parental use in the present study which is similar to the findings reported by Sinha et al 2003. ${ }^{12}$ Among the ever tobacco users 34 (19\%) started using it before the age of 10 years, which is a matter of concern due to down ward shift of the tobacco initiation age. GYTS from North east states (NES) and GYTS-Uttar Pradesh reported over 65 and $72 \%$ of students respectively begin tobacco use before 10 years of age. ${ }^{13-15}$ Similar results have been reported from small studies done in rural areas of Gujarat, Tamil Nadu, Karnataka and Goa where one-third to one-half of children under the age of 10 years experimented with smoking or smokeless tobacco in some form. ${ }^{15,17}$

\section{Conclusion and Recommendations}

Age at initiation of tobacco use among the school children in rural areas is decreasing and children are falling prey 
Table 4: Distribution according to age of initiation

\begin{tabular}{|c|c|c|c|c|c|c|}
\hline \multirow[t]{2}{*}{ Habits } & & & \multicolumn{4}{|c|}{ Gender } \\
\hline & & & \multicolumn{2}{|c|}{$\begin{array}{c}\text { Boys } \\
N=2310\end{array}$} & \multicolumn{2}{|c|}{$\begin{array}{c}\text { Girls } \\
N=1216\end{array}$} \\
\hline \multicolumn{6}{|c|}{ Tobacco chewers } & \\
\hline \multirow[t]{7}{*}{ Age } & $<10$ years & $8-9$ years & $07(0.3 \%)$ & $19(0.8 \%)$ & 0 & 0 \\
\hline & & $9-10$ years & $12(0.5 \%)$ & & 0 & \\
\hline & $>10$ years & $10-11$ years & $09(0.3 \%)$ & $65(2.8 \%)$ & & \\
\hline & & $11-12$ years & $13(0.5 \%)$ & & $1(0.05 \%)$ & 3 \\
\hline & & $12-13$ years & $12(0.5 \%)$ & & $2(0.15 \%)$ & $(0.2 \%)$ \\
\hline & & $13-14$ years & $14(0.6 \%)$ & & & \\
\hline & & $14-15$ years & $17(0.9 \%)$ & & & \\
\hline \multicolumn{7}{|c|}{ Tobacco smokers } \\
\hline \multirow[t]{7}{*}{ Age } & $<10$ years & $8-9$ years & $03(0.1 \%)$ & $11(0.4 \%)$ & $0(0 \%)$ & \\
\hline & & $9-10$ years & $08(0.3 \%)$ & & & \\
\hline & $>10$ years & $10-11$ years & $06(0.3 \%)$ & $46(1.9 \%)$ & $0(0 \%)$ & \\
\hline & & $11-12$ years & $09(0.4 \%)$ & & & \\
\hline & & $12-13$ years & $10(0.4 \%)$ & & & \\
\hline & & $13-14$ years & $09(0.4 \%)$ & & & \\
\hline & & $14-15$ years & $12(0.5 \%)$ & & & \\
\hline \multicolumn{7}{|c|}{ Both chewing and smoking } \\
\hline \multirow[t]{7}{*}{ Age } & $<10$ years & $8-9$ years & $00(0.0 \%)$ & $04(0.1 \%)$ & $0(0 \%)$ & \\
\hline & & $9-10$ years & $04(0.1 \%)$ & & & \\
\hline & $>10$ years & $10-11$ years & $06(0.2 \%)$ & $34(1.4 \%)$ & $0(0 \%)$ & \\
\hline & & $11-12$ years & $09(0.4 \%)$ & & & \\
\hline & & $12-13$ years & $04(0.1 \%)$ & & & \\
\hline & & $13-14$ years & $08(0.4 \%)$ & & & \\
\hline & & $14-15$ years & $07(0.3 \%)$ & & & \\
\hline
\end{tabular}

to this silent killer at a very early age of life. It becomes imperative to implement and reinforce the tobacco related policies and provide suitable school environment to the children to curb the tobacco menace. Medical officers and dental surgeons involved in screening of school children under school health programs can be trained to deliver health education sessions pertaining to harmful effects of tobacco use in the schools to curb the tobacco menace among the children.

\section{REFERENCES}

1. Sinha DN, Reddy KS, Rahman K, Warren CW, Jones NR, Asma S. Linking global youth tobacco survey (GYTS) data to the WHO framework convention on tobacco control: the case for India. Ind J Public Health 2006;50(2):76-89.

2. World health organization (WHO) report on the global tobacco epidemic-executive summary 2011.

3. Jha P, Chaloupka FJ. Curbing the epidemic: governments and the economics of tobacco control. Washington DC, The World Bank 1999.

4. Johnson N. Tobacco use and oral cancer: a global perspective. J Dent Educ 2001;65(4):328-339.

5. Chakrabarti RN, Dutta K, Sikdar S, Ghosh K. Smokeless tobacco and premalignant and malignant lesions of the oral cavity. Indian J Med Sci 1991;45(10):273-275.
6. Mirbod SM, Ahing SI. Tobacco associated lesions of the oral cavity: Part I. Nonmalignant lesions. J Can Dent Assoc 2000; 66(5):252-256.

7. Reibel J. Tobacco and oral diseases. Update on the evidence, with recommendations. Med Princ Pract 2003;12(S1):22-32.

8. India global youth tobacco survey (GYTS), 2006.

9. Bala DV, Bodiwala IN, Patel DD, Shah PM. Epidemiological determinants of tobacco use in Gujarat state, India. Ind J Comm Med 2006;31(3):173-176.

10. Narain R, Sardana S, Gupta S, Sehgal A. Age at initiation and prevalence of tobacco use among school children in Noida, India: a cross-sectional questionnaire based survey. Ind J Med Res 2011;133(3):300-307.

11. Kapil U, Goindi G, Singh V, Kaur S, Singh P. Consumption of tobacco, alcohol and betel leaf amongst school children in Delhi. Ind J Pediatr 2005;72(11):993.

12. Sinha DN, Gupta PC, Pednekar MS. Tobacco use among students in the eight north-eastern states of India. Ind J Cancer 2003;40(2):43-59.

13. Jindal SK. Global youth tobacco survey, Haryana 2003.

14. Jindal SK. Global youth tobacco survey, Chandigarh 2003.

15. Sinha DN. Report on the results of the global youth tobacco survey in Uttar Pradesh, 2002.

16. Pednekar MS, Gupta PC. Tobacco use among school students in Goa, India. Ind J Public Health 2004;48(3):147-152.

17. Krishnamurthy S, Ramaswamy R, Trivedi U, Zachariah V. Tobacco use in rural Indian children. Ind Pediatr 1997;34(10): 923-927. 